\title{
Inactivation of the human $\beta$-globin gene by targeted insertion into the $\beta$-globin locus control region
}

\author{
Chul G. Kim, ${ }^{1}$ Elliot M. Epner, ${ }^{1}$ William C. Forrester, ${ }^{1,3}$ and Mark Groudine ${ }^{1,2}$ \\ ${ }^{1}$ Fred Hutchinson Cancer Research Center, Seattle, Washington 98104 USA; ${ }^{2}$ Department of Radiation Oncology, University \\ of Washington School of Medicine, Seattle, Washington 98195 USA
}

The human $\beta$-globin locus control region (LCR) is a complex regulatory element that controls the erythroid-specific expression of all cis-linked globin genes. The LCR is composed of five DNase I hypersensitive sites (HS) spanning $16 \mathrm{~kb}$ and located $>50 \mathrm{~kb}$ upstream of the $\beta$-globin gene on chromosome 11. Constructs containing all or some of these HS have been shown to produce high-level erythroid-specific expression of linked genes in transgenic mice and transfected cells. In all transgenic and transfection experiments reported to date, however, the spatial relationships between the LCR and globin genes have been disrupted. We have used homologous recombination (HR) as an approach to gain insights into the potential interactions between the LCR and globin genes in their native locations. A hygromycin $B$ resistance $\left(\right.$ hygro $^{\mathrm{R}}$ ) gene was inserted into the human $\beta$-globin LCR on chromosome 11 in a mouse/human hybrid erythroid cell line that expresses the human $\beta$-globin gene after the induction of differentiation. As a consequence of this targeted insertion, the $\beta$-globin gene is transcriptionally inactive and not inducible. In contrast, the hygro ${ }^{R}$ gene within the LCR is inducible, whereas randomly integrated hygro ${ }^{R}$ genes are not inducible in these cells. The chromatin structure of the targeted locus is also altered. A new DNase I HS is present in the enhancer/promoter of the hygro ${ }^{R}$ gene inserted into the LCR, whereas a HS normally present in the LCR $3^{\prime}$ to the insertion is lost and the $\beta$-globin gene promoter HS is not detectable. These results are consistent with the promoter/enhancer competition model for LCR function and globin gene switching.

[Key Words: Homologous recombination; LCR; promoter/enhancer competition; human $\beta$-globin gene; human/MEL hybrid]

Received February 20, 1992; revised version accepted March 24, 1992.

The human $\beta$-globin locus is composed of five linked functional $\beta$-like globin genes that span $\sim 50 \mathrm{~kb}$ on chromosome 11. These genes are arranged in the same transcriptional orientation and in the order in which they are expressed developmentally. The human $\beta$-globin locus control region (LCR), located $6-22 \mathrm{~kb}$ upstream of the $\boldsymbol{\epsilon}$-globin gene on chromosome 11 , is a recently recognized regulatory unit that controls the replication timing, chromatin structure, and transcription of the $\beta$-globin domain (for review, see Epner et al. 1991). The LCR has been operationally defined by five DNase I hypersensitive sites $\left(5^{\prime} \mathrm{HS} 1-5^{\prime} \mathrm{HS} 5\right)$, four of which are erythroid specific, developmentally stable (Tuan et al. 1985; Forrester et al. 1986), and present prior to transcriptional activation of the globin genes (Forrester et al. 1987). The contribution of $5^{\prime} \epsilon$ elements to expression of all cislinked globin genes was surmised originally from the phenotype of naturally occurring deletions of this region, which result in the failure to activate the linked globin

${ }^{3}$ Present address: Department of Microbiology and Immunology, University of California, San Francisco, California 94143 USA. genes (Curtin et al. 1985; Van der Ploeg et al. 1986; Driscoll et al. 1989). Detailed analysis of the Hispanic $(\gamma \delta \beta)^{\circ}$ thalassemia, in which a $35-\mathrm{kb}$ region $5^{\prime}$ of $5^{\prime} \mathrm{HS} 1$ of the LCR (located $\sim 50 \mathrm{~kb}$ upstream of the $\beta$-globin gene) is deleted, has not only implicated the LCR with transcriptional regulation but also with the establishment of the erythroid-specific DNase I-sensitive chromatin domain and timing of DNA replication of the locus. In this disorder, no transcription of the $\beta$-globin gene on the deletion chromosome is observed, and the locus is DNase I resistant and replicated late in S phase (Driscoll et al. 1989; Forrester et al. 1990). This is in contrast to the normal allele in which the $\beta$-globin gene is expressed and the locus is DNase I sensitive and replicated early in S phase (Epner et al. 1988; Forrester 1990). Thus, in addition to the classical enhancer effects revealed in transfection and transgenic assays (see below), the LCR also influences the chromatin structure and replication timing of the locus.

Functional assays have shown that various LCR elements can overcome the position effects exhibited by constructs integrated randomly into chromosomal loca- 
tions. Initially, a 38-kb minilocus containing the LCR was shown to alleviate position effects in transgenic mice: A construct containing the LCR linked to the $\beta$-globin gene demonstrated copy number-dependent expression and expression levels equivalent to the endogenous mouse $\beta$-globin genes (Grosveld et al. 1987). Similar results were also observed in subsequent transgenic studies, in which subsets of the LCR were linked to the $\beta$-globin gene (Curtin et al. 1989; Ryan et al. 1989; Talbot et al. 1989; Enver et al. 1990). In combination with $\beta$-globin promoter sequences, the LCR also confers highlevel, erythroid-specific expression in transfected cell lines (Blom van Assendelft et al. 1989; Forrester et al. 1989). Although, as in transgenic mice, the strongest effects are seen when all of the HS are linked together, some individual sites can also augment transcription (Forrester et al. 1989; Tuan et al. 1989; Collis et al. 1990). These effects vary, depending on whether transient or stable assays are employed. Transfection studies performed in MEL cells showed that $5^{\prime} \mathrm{HS} 2,5^{\prime} \mathrm{HS} 3$, and $5^{\prime} \mathrm{HS} 4$ all elevate expression of linked $\beta$-globin genes (Forrester et al. 1989; Collis et al. 1990) when stably integrated into the chromosome. However, only $5^{\prime} \mathrm{HS} 2$ shows enhancer activity in transient assays in murine erythroid leukemia (MEL) and K562 cells (Tuan et al. 1989; Moon and Ley 1991). Elements analogous to the human $\beta$-globin LCR have also been identified in the chicken (Reitman et al. 1990), goat (Li et al. 1990), and mouse (Moon and Ley 1990| $\beta$-globin and human $\alpha$-globin loci (Higgs et al. 1990).

Recent transgenic studies also suggest that the human LCR may be involved in stage-specific globin gene switching (Behringer et al. 1990; Enver et al. 1990; Hanscombe et al. 1991) in a manner analogous to the enhancer competition model described for chicken $\beta$-like globin gene switching (Choi and Engel 1988). The essence of this and derivative models (Evans et al. 1990; Orkin 1990; Townes and Behringer 1990; Stamatoyannopoulos 1991) is that the stage-specific expression of any globin gene is dependent on the presence of positive factors that allow a high-affinity interaction between that gene and the enhancer within the LCR, and/or the presence of stage-specific autonomous silencing of the other globin genes.

An important limitation in interpreting the analyses of LCR function in transgenic and transfection assays is that the spatial relationships between the LCR and cislinked globin genes have been disrupted in all such experiments. Thus, as an approach to gain further insights into the potential interactions among the LCR and globin genes in their native locations, we have performed homologous recombination (HR) into the human $\beta$-globin LCR. Here, we report that insertion of a hygromycin B-resistance $\left(\right.$ hygro $^{\mathrm{R}}$ ) gene driven by the Friend viral long terminal repeat (LTR) enhancer/promoter between $5^{\prime} \mathrm{HS} 1$ and $5^{\prime} \mathrm{HS} 2$ in the $\beta$-globin LCR abolishes expression of the human $\beta$-globin gene located $>50 \mathrm{~kb}$ downstream of the insertion site. The inserted hygro ${ }^{\mathrm{R}}$ gene located within the LCR shows inducible expression, whereas randomly integrated hygro ${ }^{R}$ genes are not inducible. Chromatin analyses reveal a new DNase I HS in the Friend virus promoter/enhancer, whereas $5^{\prime} \mathrm{HS} 1$ in the LCR region and the $\beta$-globin promoter HS are eliminated. These results present evidence that the LCR influences the inducible expression of the downstream $\beta$-globin gene from its natural position. We speculate that the inactivation of the $\beta$-globin gene may involve competition between the Friend viral LTR and the $\beta$-globin gene for elements of the LCR in a manner analogous to that proposed by Choi and Engel (1988).

\section{Results}

\section{Isolation of homologous recombinants}

The positive-negative selection strategy described by Capecchi and colleagues (Mansour et al. 1988; Capecchi 1989) was used to construct a replacement-type vector (Fig. 1) designed to insert a selectable marker gene into the human $\beta$-globin LCR by a double crossover event. This vector contains $1 \mathrm{~kb}$ of $5^{\prime}$ homology and $8 \mathrm{~kb}$ of $3^{\prime}$ homology, including $5^{\prime} \mathrm{HSl}$ and part of the $\epsilon$-globin gene. The positive-selection hygro ${ }^{\mathrm{R}}$ marker gene is inserted at a unique $\mathrm{Hpal}$ site $\sim 7.5 \mathrm{~kb}$ upstream of the $\epsilon$-globin gene, and the negative-selection marker gene, herpes simplex virus (HSV) thymidine kinase (tk), is placed outside the $3^{\prime}$ homologous sequences (for details of construction, see Materials and methods|. The Friend virus enhancer/promoter, which is active in many cell types and shows high-level expression in erythroid cells (Cowie and Myers 1988), was used to drive both selectable marker genes. Correctly targeted integration of this vector by $H R$ will result only in the insertion of the hygro $^{\mathrm{R}}$ gene between $5^{\prime} \mathrm{HS} 1$ and $5^{\prime} \mathrm{HS} 2$, with no alterations in LCR sequences per se.

The linearized vector was electroporated into a human lymphoid/MEL hybrid cell line (N-MEL) containing a single normal human chromosome 11 . As described previously (Forrester et al. 1987; 1990), these cells are adultstage erythroid cells in which only the adult $\beta$-globin gene is transcribed and the entire human $\beta$-globin gene domain spanning $>100 \mathrm{~kb}$ is DNase I sensitive and early replicating. After selection with hygromycin B and gancyclovir, pools of cells resistant to both drugs were screened by polymerase chain reaction (PCR) and Southern blot analysis (Kim and Smithies 1988). Two primers were used for PCR amplification: Primer 99 is located outside and $\sim 100 \mathrm{bp}$ upstream of the targeting vector, and primer $\mathrm{Hl}$ is derived from sequences in the hygro ${ }^{\mathrm{R}}$ gene and is specific to the vector DNA (Fig. 1). If a targeting event juxtaposes these two primers, specific PCR amplification should result in a diagnostic $1.5-\mathrm{kb}$ band that hybridizes to a $1.0-\mathrm{kb} 5^{\prime} \in \mathrm{EcoRI}-\mathrm{HpaI}$ probe. Sib selections from the pool that demonstrated the strongest specific hybridization signal were performed serially, with $\sim 100, \sim 10$, and $\sim 1$ cell per pool in 24-, 48-, and 96-well plates, respectively. During the sib selection, the enriched pools were diluted into 96 -well plates so that only $30-50 \%$ of the wells received a cell. After growth to adequate density, samples were removed and analyzed 
A

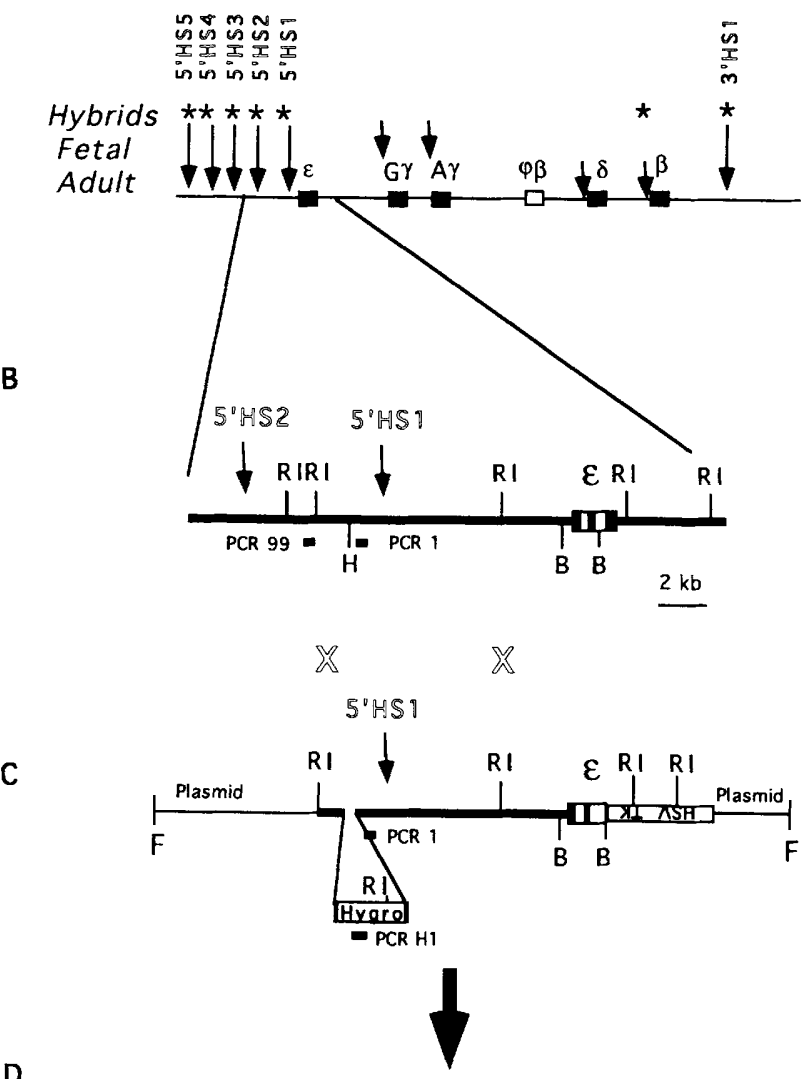

D

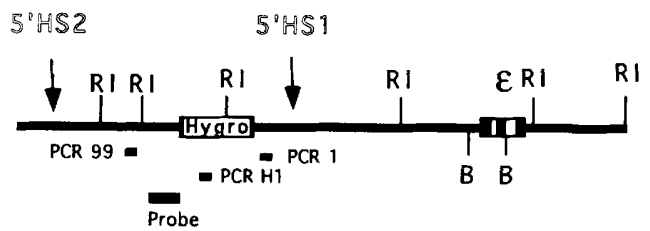

Figure 1. Homologous recombination into the human $\beta$-globin LCR. (A) Schematic map of the human $\beta$-globin locus showing the positions of the HS and the arrangement of $\beta$-globin-coding genes. $(B)$ Enlarged region of $A$ to show the targeting locus. $|C|$ The targeting construct aligned with a chromosomal copy of this region. The hygro ${ }^{\mathrm{R}}$ gene is inserted into the unique $\mathrm{HpaI}$ site between $5^{\prime} \mathrm{HSl}$ and $5^{\prime} \mathrm{HS} 2$, and the HSV tk gene is juxtaposed 3 ' of the 6 -globin second intron region /see Materials and methods). (D) Homologous recombination between genomic DNA $(B)$ and the targeting vector $(C)$. In $A$, solid and open rectangles represent the functional and nonfunctional globin genes, respectively. In $B, C$, and $D$ the solid and open boxes represent exons and introns in the $\epsilon$-globin gene, respectively. Large arrows denote developmentally stable, erythroid-specific HS; small arrows represent HS within the promoters of the fetal and adult $\beta$-genes. The asterisks $\left({ }^{*}\right)$ above the arrows indicate the subsets of HS that are found in the parent MEL/human hybrid cells. PCR primers are indicated with identifying numbers. The probe for the PCR-Southern analysis is also indicated by the horizontal bar. Restriction sites are as follows: $(\mathrm{B}) \mathrm{BamHI}$ ( $\mathrm{F})$ FspI; (H) HpaI; (RI) EcoRI.

by PCR. Of 81 clones tested, 8 showed the correct sized band in ethidium bromide-stained agarose gels (data not shown).
Figure 2 shows a Southern blot analysis of DNA from parental cells and the eight presumptive targeted clones cut with BglII and probed with junction and hygro ${ }^{\mathrm{R}}$ probes. If a correct targeting event has occurred, both probes should detect a $4.4-\mathrm{kb}$ band in the recombinants, whereas the junction probe, but not the hygro ${ }^{R}$ probe, should detect a 7.7-kb band in parental DNA. In seven of eight clones the predicted $4.4-\mathrm{kb}$ band was detected by the $5^{\prime}$ junction probe (probe 1, Fig. 2A). No band, however, was observed in clone 1 , whereas two clones $(2$ and 6 ) had additional $\sim 9-\mathrm{kb}$ bands, suggesting that these clones are not pure or contain multiple rearrangements. In contrast, in three of five clones showing the single expected band hybridizing to the junction probe, the single predicted $4.4-\mathrm{kb}$ band was detected by the hygro ${ }^{\mathrm{R}}$ probe, whereas the other two clones showed additional bands (Fig. 2B). Thus, this analysis suggests that three targeted clones (HR9, HR20, and HR39) contain a single insertion at the desired location, whereas others contain additional nonhomologous insertions or are not homogeneous clones. The homogeneity, correct targeting, and integrity of the $\beta$-globin locus of clones HR9, HR20, and HR39 were confirmed by Southern analyses using several additional restriction enzymes and probes (data not shown).

\section{Gene expression}

Total cellular RNA was prepared from the three singlecopy targeted clones before and after hexamethylene bisacetamide (HMBA)-induced differentiation, and globin RNA content was determined by an RNase protection assay. Surprisingly, human $\beta$-globin gene expression is not detectable in the three targeted clones, whereas mouse $\alpha$ - and $\beta$-globin (not shown) are expressed at high levels in both HMBA-induced parental and recombinant cells (Fig. 3A). In addition, the human $\gamma$-globin gene, which is not expressed in normal human/ MEL hybrids, is not expressed in our targeted clones (data not shown). However, the hygro ${ }^{\mathrm{R}}$ gene inserted into the LCR region by homologous recombination is expressed and induced to high levels during the in vitro differentiation of the homologous recombinant clones. The induction of hygro ${ }^{R}$ is observed independent of maintenance of the targeted clones in selective media. Although the hygro ${ }^{\mathrm{R}}$ gene shows high-level HMBA-dependent inducible expression in the three homologous recombinant clones (Fig. 3A), the basal expression of this gene is not inducible during the in vitro differentiation of clones containing nonhomologous integrants (Fig. 3B). These results suggest that the inducible effect of the LCR remains functional in the targeted $\beta$-globin gene locus, but the inserted and LCR-proximal hygro ${ }^{R}$ gene may replace the downstream $\beta$-globin gene as the recipient of this effect (see Discussion).

It should be noted, however, that individual subclones of parental hybrid cells that do not contain the homologously inserted hygro ${ }^{\mathrm{R}}$ gene display substantial variation in human $\beta$-globin gene expression, as assayed by RNase protection or by immunofluorescence with an allele-spe- 
A.

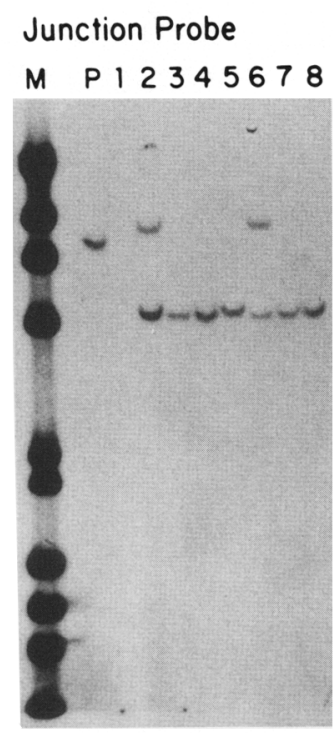

B.

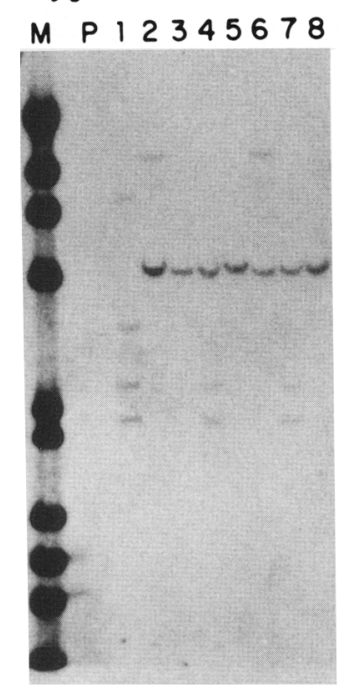

C.

$N-M E L$

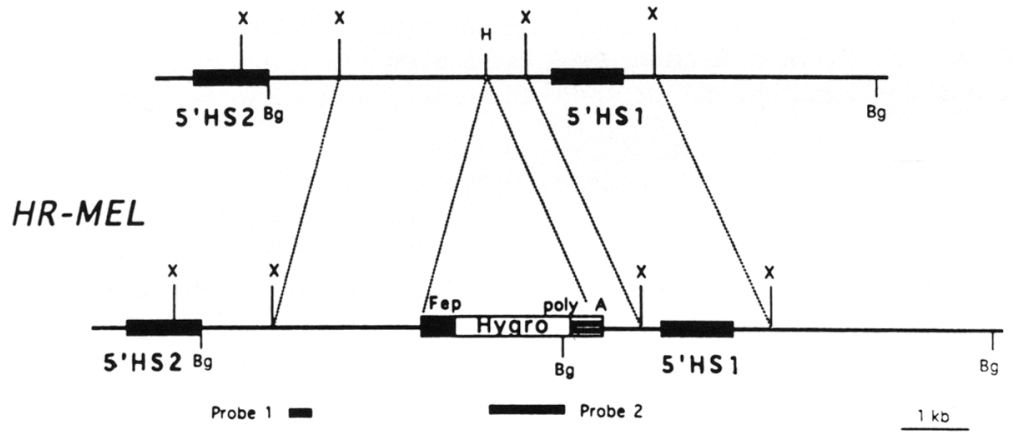

Figure 2. Southern blot hybridization of genomic DNA from putative homologous recombinants. After electroporation and positive-negative double selection, PCR positive cells were sib selected and genomic DNA from eight putative clones was cleaved with BgIII (lanes 1-8). Control DNA from untransfected parent cells (lane $P$ ) was also included in Southern blot hybridization. Southern blots were hybridized with a $0.3-\mathrm{kb} 5^{\prime} \epsilon$ EcoRI-EcoRV junction probe (probe 1 in $C)(A)$ and a $1.0-\mathrm{kb} N$ col-BglII fragment from the hygro ${ }^{\mathrm{R}}$ gene (probe 2 in $\left.C\right)(B) .(C)$ Relevant restriction maps of parent (N-MEL) and homologous recombinant (HR-MEL). The HR-MEL restriction map shows the insertion of the Friend virus enhancer/promoter (Fep), hygro ${ }^{\mathrm{R}}$ gene, and SV40 poly(A) addition and termination sites [poly(A)] between $5^{\prime} \mathrm{HS} 1$ and $5^{\prime} \mathrm{HS} 2$. The junction probe detects a $7.7-\mathrm{kb}$ band in control N-MEL DNA and a $4.4-\mathrm{kb}$ band in HR-MEL DNA. The hygro ${ }^{\mathrm{R}}$ probe does not hybridize to control DNA and detects the same 4.4$\mathrm{kb}$ band in HR-MEL DNA. Restriction enzyme sites are as follows: $(\mathrm{Bg}) \mathrm{BgIII} ;(\mathrm{H}) \mathrm{HpaI} ;(\mathrm{X}) \mathrm{XbaI}$. cific human $\beta$-globin antibody (Shesely et al. 1991 and data not shown). Thus, it is possible that the absence of human $\beta$-globin expression in the targeted clones originated in a variant cell within the original parent cell clonal population. This type of variability in expression, known as extinction, has been reported to be attributable to random de novo methylation of genomic DNA, which occurs continually during cell culture (e.g., Antequera et al. 1990), and is reversible by 5-azacytidine (Compere and Palmiter 1981; Groudine et al. 1981; Jones et al. 1982; Ley et al. 1982). As shown in Figure 3C, 5-azacytidine treatment of uninduced parent hybrid cells results in increased levels of human $\beta$-globin expression both before and after HMBA-induced differentiation (Fig. $3 \mathrm{C}$ ). In addition, we have observed significant increases in human $\beta$-globin gene expression in all 5 -azacytidine treated subclones of the parental cells (data not shown). In contrast, treatment of the targeted clones with 5-azacytidine has no effect on human $\beta$-globin gene expres- sion before or after HMBA-induced differentiation. Therefore, it seems likely that the lack of human $\beta$-globin gene expression in targeted clones is not the result of a methylation event in a subset of cells from the original population but is due to the targeted insertion of the hygro ${ }^{\mathrm{R}}$ gene.

\section{Chromatin structure}

We have demonstrated previously that the chromatin structure of the human $\beta$-globin domain is faithfully reproduced in MEL cell hybrids containing a chromosome 11 derived from either human lymphoid cells or fibroblasts (Forrester et al. 1987; 1990). To determine whether the failure to activate $\beta$-globin gene expression in our targeted clones is related to the formation of the developmentally stable and/or gene-specific HS in the globin gene domain, we analyzed the chromatin structure of the $\beta$-globin gene locus in the HR clones. 

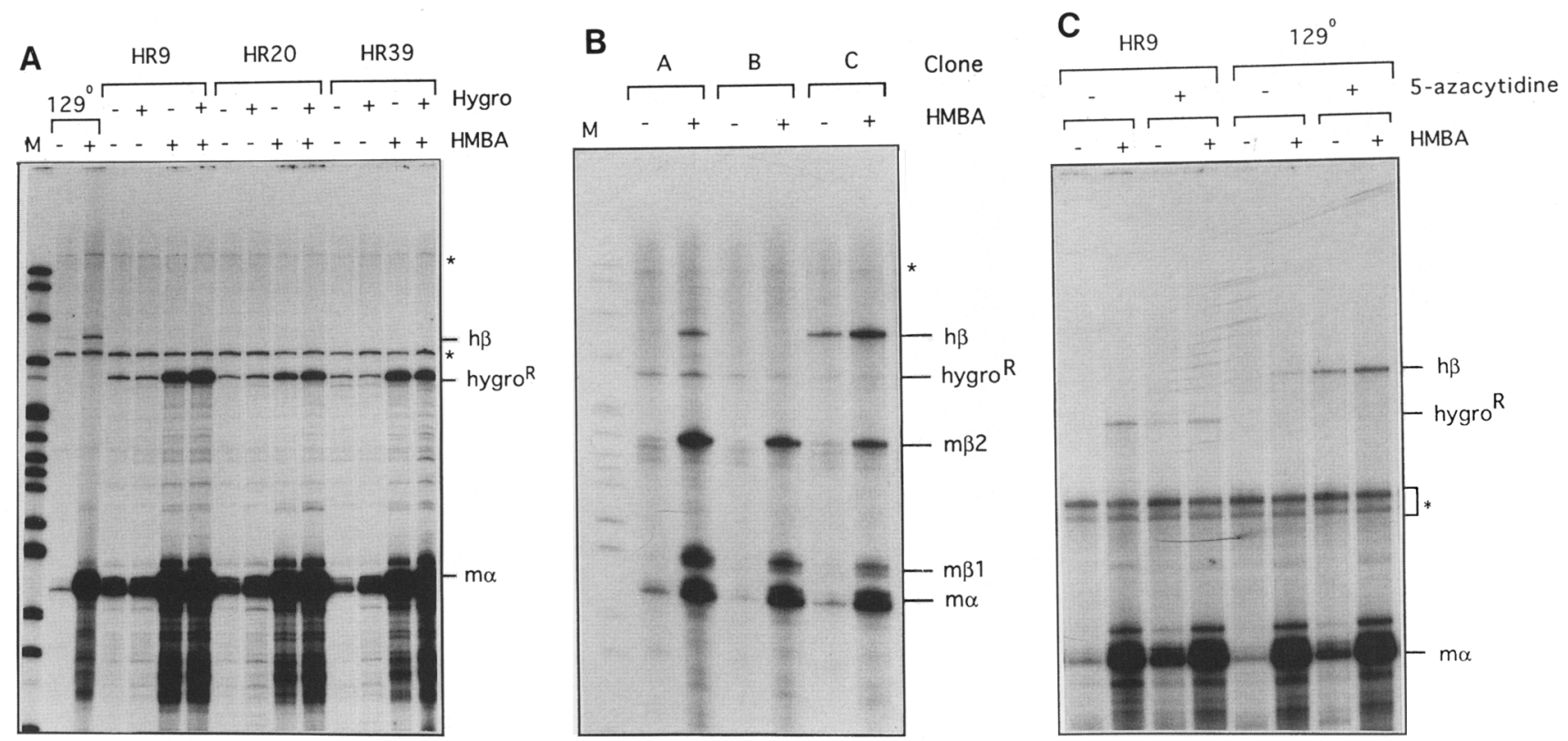

Figure 3. Analysis of globin gene expression. $(A)$ RNase protection assays of HR. Total cellular RNA was prepared from uninduced $1-\}$ and HMBA induced (+) parental MEL/human hybrid cells $\left(129^{\circ}\right)$ or three clones of HR (HR9, HR20, and HR39, which correspond to clones 3,5 , and 8 in Fig. 2, respectively) cultured in the presence $|+|$ or absence $|-|$ of selection (see text). RNase protection analysis was performed by an established method (see Materials and methods) with mouse $\alpha$-globin (m $\alpha$ ), human $\beta$-globin (h $\beta$ ), and hygro ${ }^{\mathrm{R}}$ gene $\left(\right.$ hygro $\left.{ }^{\mathrm{R}}\right)$ probes. The locations of protected fragments corresponding to each gene are indicated. Bands marked by asterisks $\left({ }^{*}\right)$ indicate residual undigested probes. $(M)$ pBR322 MspI-cut DNA molecular weight markers. $(B)$ RNase protection assays of three independent nonhomologous recombinant clones. Clone B represents a clone that does not contain human chromosome 11 . Bands labeled $\mathrm{m} \beta 1$ and $\mathrm{m} \beta 2$ correspond to mouse $\beta$-globin exons 1 and 2 , respectively. $(C)$ RNase protection assays of 5-azacytidine-treated parent and HR cells. Cells were treated with 5 -azacytidine for $20 \mathrm{hr}$ at a final concentration of $3 \mu \mathrm{M}$, and then the cells were allowed to recover in culture for 1 week.

Nuclei from targeted clone HR9 (HR-MEL), from a subclone of the parental hybrid in which the human $\beta$-globin is expressed (N-MEL), and a hybrid in which human $\beta$-globin expression is extinguished (X-MEL) were treated with DNase I, and Southern blot analyses were performed on the purified DNAs. As shown in Figure 4A, hybridization of BamHI-restricted samples with end-labeled probe $A\left(1.7-\mathrm{kb} 5^{\prime} \epsilon B g I I I-E c o R V\right.$ fragment) reveals the presence of $5^{\prime} \mathrm{HS} 1$ and $5^{\prime} \mathrm{HS} 2$ in the high expressing and extinguished cells. Similar analysis of the HR clone (HR-MEL) reveals the expected sub-band indicative of $5^{\prime} \mathrm{HS} 2$, but the $5^{\prime} \mathrm{HS} 1$ sub-band signal is reduced significantly and a new HS is detected in the inserted Friend virus enhancer/promoter region. The presence of this novel HS and the absence of 5'HS1 in the targeted clone were confirmed by hybridization of BamHI-digested samples with probe B $\left(1.3-\mathrm{kb} 5^{\prime} \epsilon\right.$ HindIII-BamHI fragment), which labels the other end of the restriction fragment (Fig. 4B). Hybridization of EcoRI-digested samples with probe $C\left(0.8-\mathrm{kb} 5^{\prime} \epsilon\right.$ NcoI-BgIII fragment) reveals the expected $10.2-\mathrm{kb}$ parental fragment and subbands corresponding to $5^{\prime} \mathrm{HS} 2,5^{\prime} \mathrm{HS} 3$, and 5'HS4 in the control and homologous recombinant cells (Fig. 4C), as well as in the extinguished cells (not shown). Additional analyses revealed that $5^{\prime} \mathrm{HS} 5\left(21.5-\mathrm{kb} 5^{\prime}\right.$ to $\left.\epsilon\right)$ and $3^{\prime} \mathrm{HS} 1$ $\left(21.8-\mathrm{kb}^{\prime}\right.$ to $\left.\beta\right)$ were formed in both control and targeted clones (not shown). Thus, the insertion of our targeting vector into the LCR does not result in a global change in chromatin structure of the $\beta$-globin locus. Rather, within the LCR, the detectable changes are the loss of $5^{\prime} \mathrm{HS} 1$ and the formation of a new promoter/enhancerbased HS in the inserted Friend virus LTR. Analyses of the other homologous recombinant clones /HR20 and HR39| revealed similar changes in the chromatin structure of the LCR (data not shown).

We also analyzed the human $\beta$-globin gene promoter HS, which is associated with the expression of this gene in normal adult erythroid cells and MEL/human hybrids (Groudine et al. 1983; Forrester et al. 1987). A Southern blot of EcoRI-digested samples from control, targeted, and extinguished cells was hybridized with a $0.6-\mathrm{kb}$ Hincll fragment located $5^{\prime}$ to the $\beta$ globin gene. As shown in Figure 5, the HS in the promoter region is formed as expected in N-MEL chromatin but is not detected in HR-MEL or in X-MEL chromatin. Previously reported minor HS located upstream of the promoter HS (Groudine et al. 1983) are detectable in these hybrid cells and are more prominent in HR-MEL and X-MEL owing to the absence of the promoter HS in these cells (Fig. 5).

Thus, our analysis of the chromatin structure of these cell lines reveals that the HS associated with expression of the human $\beta$-globin gene is absent in cell lines in 
A
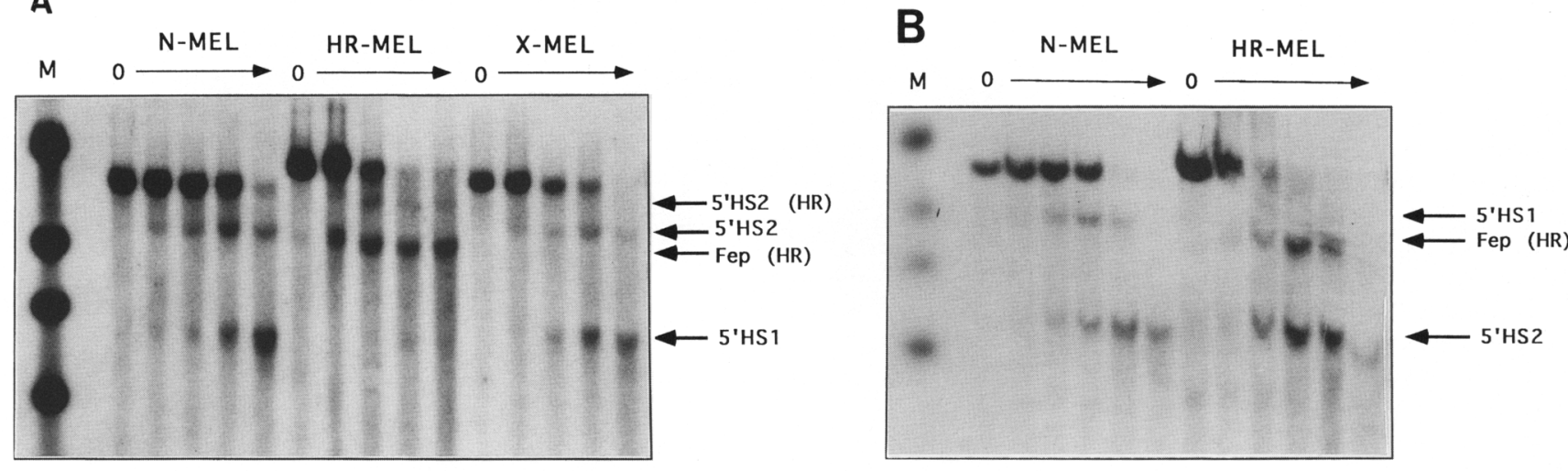

D
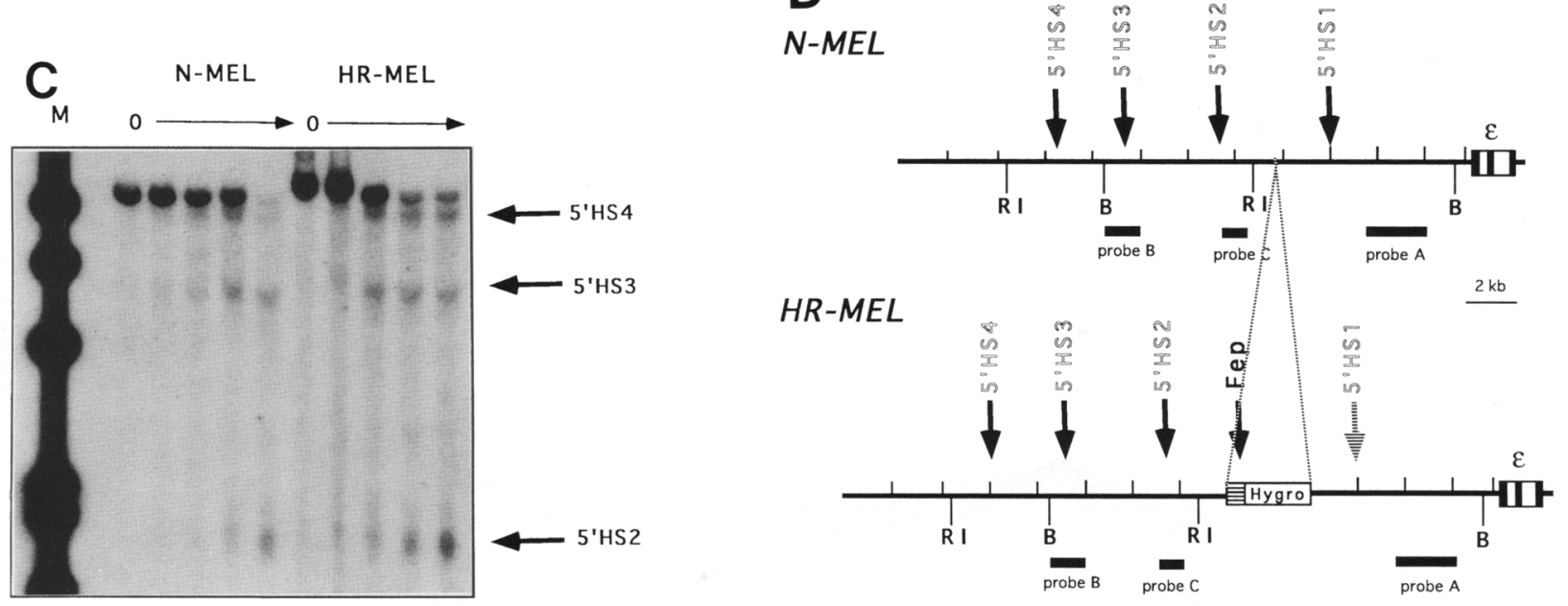

Figure 4. Chromatin structure in the LCR. After digestion of nuclei with DNase I at increasing concentrations (indicated by direction of the arrow above each sample), the DNA was purified, digested with BamHI, and blot-hybridized to a $1.7-\mathrm{kb} 5^{\prime} \epsilon B g l \mathrm{II}-E c o \mathrm{RV}$ fragment (probe A in $D)(A)$ or a 1.3-kb 5' $\epsilon$ HindIII-BamHI fragment (probe B in $D)(B)$. Both probes detect a 15.0-kb BamHI fragment in parent MEL/human hybrid clones that show high (N-MEL) or no (X-MEL) expression of the human $\beta$-globin gene after HMBA induction, and a 17.5-kb BamHI fragment in the HR9 clone (HR-MEL). In A, sub-bands of 5.5 and $10.0 \mathrm{~kb}$ represent 5'HS1 and 5'HS2, respectively, and are detected in both N-MEL and X-MEL. In HR-MEL, 9.5- and 12.5-kb sub-bands correspond to the new HS in the Friend virus LTR and 5'HS2, respectively. In $B$, a 5.0-kb sub-band corresponding to $5^{\prime} \mathrm{HS} 2$ is detected in all samples, whereas a $9.5-\mathrm{kb}$ sub-band corresponding to $5^{\prime} \mathrm{HS} 1$ is seen in both N-MEL and X-MEL and a $8.5-\mathrm{kb}$ sub-band representing a new HS in the Friend virus LTR appears in HR-MEL. Sub-bands corresponding to each HS are indicated by arrows at right labeled HS. (M) Molecular weight standards of HindIII $\lambda$ and HaeIII-digested $\phi x 174$ DNAs. (C) EcoRI-digested DNA samples were blot hybridized with 0.8-kb 5'€ NcoI-Bglll fragment (probe $\mathrm{C}$ in $D$ ) to detect $5^{\prime} \mathrm{HS} 2,5^{\prime} \mathrm{HS} 3$, and $5^{\prime} \mathrm{HS} 4$. This probe detects a 10.2 -kb parent EcoRI band in all samples and sub-bands of $1.6,5.7$, and $9.0 \mathrm{~kb}$ representing $5^{\prime} \mathrm{HS} 2,5^{\prime} \mathrm{HS} 3$, and 5'HS4, respectively. $(D)$ Simplified maps of N-MEL and HR-MEL. HS are depicted by solid arrows; stippled arrows represent the loss of an HS. The EcoRI (RI) and BamHI (B) restriction sites are also indicated. Probes used in $A, B$, and $C$ are shown below the map.

which the gene is inactive. However, all LCR HS remain intact in control cells and cells in which the gene is inactivated by extinction, whereas the insertion of hygro $^{\mathrm{R}}$ gene into the LCR between $5^{\prime} \mathrm{HS} 1$ and $5^{\prime} \mathrm{HS} 2$ results in formation of a new HS in the inserted promoter/enhancer region and significant reduction of the normal 5'HSl located 3' of the inserted sequences. In combination with the expression data presented in Figure 3, the chromatin structure results suggest that the inactivation of the human $\beta$-globin gene $\sim 50 \mathrm{~kb}$ downstream of the targeted region may be the result of interaction of LCR elements with the proximal Friend virus enhancer/pro- moter, preventing the normal interaction between the $\mathrm{LCR}$ and the $\beta$-globin gene promoter for proximal control elements).

\section{Discussion}

We have used the positive-negative selection homologous recombination strategy to introduce a Friend virus LTR-driven hygro ${ }^{\mathrm{R}}$ gene into the human $\beta$-globin LCR in human/MEL hybrid cells containing one copy of human chromosome 11. Our results (summarized in Fig. 6) show that $\beta$-globin gene expression and chromatin structure of 
Figure 5. Loss of $\mathrm{HS}$ in the human $\beta$-globin promoter region. A $0.6-\mathrm{kb} 5^{\prime} \beta$ HincIl fragment was used as probe for filter hybridization of the EcoRI-restricted DNAs from N-MEL, HR-MEL, and $\mathrm{X}-\mathrm{MEL}$. This probe detects a $5.4-\mathrm{kb}$ parent $E c o$ RI band and sub-bands of $3.8,3.2$, and $2.8 \mathrm{~kb}$ corresponding to one major in N-MEL) and two minor (in both HR-MEL and X-MEL) HS, respectively. The map indicates the positions of probe and HS with respect to the $\beta$-globin gene. The promoter HS observed in N-MEL is indicated by a thick arrow $\left(5^{\prime} \beta\right)$; minor HS observed upstream of the $\beta$-globin gene promoter (Groudine et al. 1983) in HR-MEL and $\mathrm{X}-\mathrm{MEL}$ are denoted by thin arrows at right.

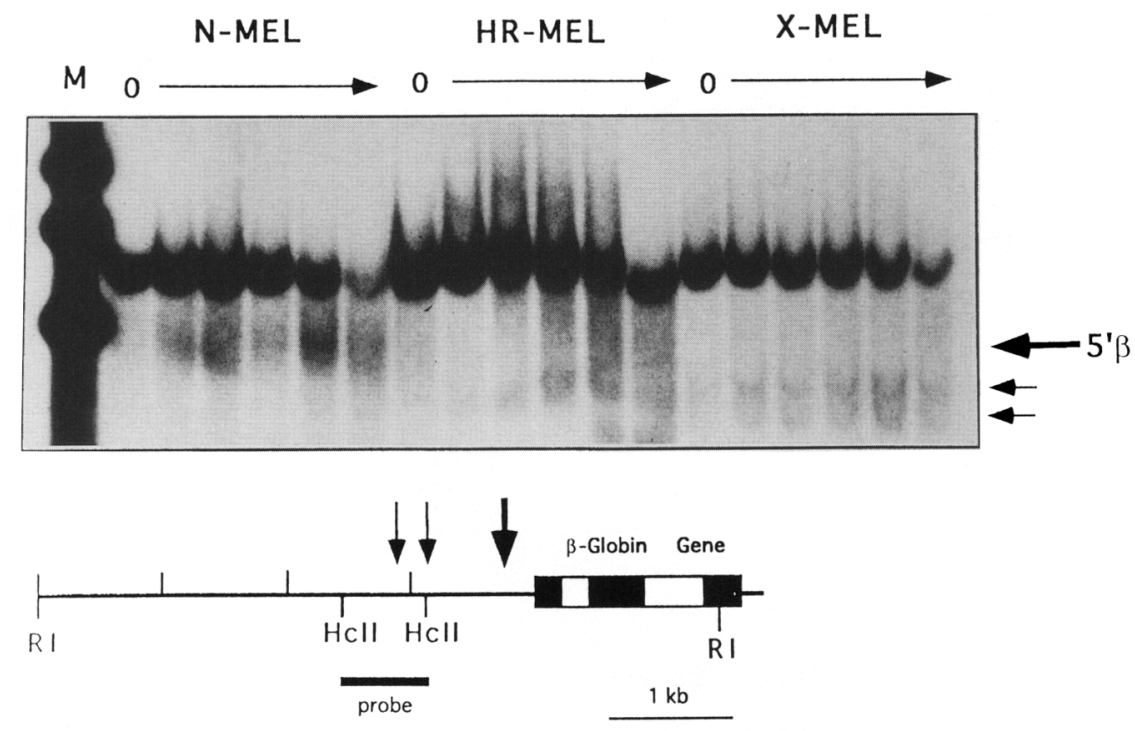

the locus are affected by insertion of the Friend virus LTR-driven hygro ${ }^{\mathrm{R}}$ gene into the $\beta$-globin LCR between $5^{\prime} \mathrm{HS} 1$ and $5^{\prime} \mathrm{HS} 2$. As shown by RNase protection assays (Fig. 3), the correctly targeted selection marker is induced to high-level expression when the cells are differentiated, whereas the human $\beta$-globin gene is no longer expressed either before or after induction. $\mathrm{Hygro}^{\mathrm{R}}$ genes integrated randomly outside the $\beta$-globin locus are not inducible. Chromatin structure studies (Figs. 4 and 5 ) show that the promoter-based HS in the $\beta$-globin gene is eliminated in the targeted clones, and a new enhancer/ promoter-based HS is formed in the Friend virus LTR, which drives transcription from the inserted hygro ${ }^{\mathrm{R}}$ gene. LCR $5^{\prime} \mathrm{HSl}$, which is displaced $2.7 \mathrm{~kb}$ downstream by insertion of the hygro ${ }^{R}$ gene, is greatly reduced or eliminated, whereas other HS in the $\beta$-globin locus (5'HS2-5'HS5 and $\left.3^{\prime} \mathrm{HS} 1\right)$ are maintained. The abrogation of human $\beta$-globin gene expression in our homologous recombinants may be attributable to the establishment of a new promoter/enhancer competition /Choi and Engel 1988), such that the hygro ${ }^{\mathrm{R}}$ gene replaces the $\beta$-globin gene as a recipient of the downstream effects of the LCR. This possibility is supported by the induction of high-level expression of the hygro ${ }^{\mathrm{R}}$ gene following HMBA treatment of the three targeted clones and the low-level constitutive expression of the hygro ${ }^{R}$ gene in clones containing nonhomologous integrants (Fig. 3).

Support for the promoter/enhancer competition model (Choi and Engel 1988) is derived from recent transgenic experiments addressing the influence of the LCR on human $\beta$-like globin gene expression. The human $\beta$-globin genes are arranged in the order in which they are expressed developmentally: Expression switches from embryonic $(\epsilon)$ in the yolk sac, to fetal $(\gamma \mid$ during intrauterine life, and to adult $(\beta)$ after birth. Transgenic experiments have shown that in the absence of the LCR, the $\epsilon$ - and $\gamma$-globin genes are silenced autonomously during later developmental stages, when the
B-globin gene is expressed (Cao et al. 1989; Raich et al. 1990; Dillon and Grosveld 1991). This silencing mechanism can not be overcome completely by the presence of the LCR. In contrast, the $\beta$-globin gene is expressed

A

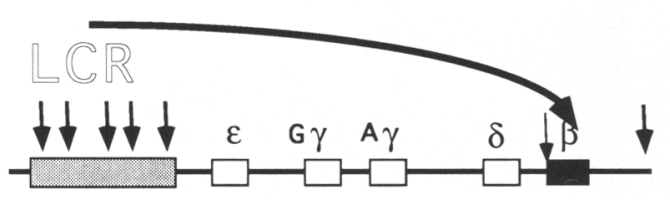

B

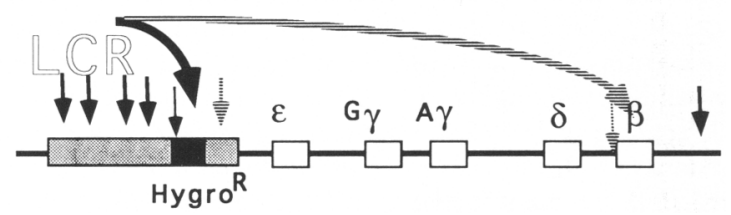

Figure 6. Summary. (A) A model of LCR-mediated activation of the human $\beta$-globin gene in N-MEL. Each $\beta$-like globin gene is shown as a rectangle /solid rectangles represent genes active in expression; open rectangles indicate transcriptionally inactive genes). The LCR is shown as a stippled rectangle. Straight arrows represent DNase I HS; thick arrows are developmentally stable and erythroid-specific HS in the LCR $\left(5^{\prime} \mathrm{HS} 1-5^{\prime} \mathrm{HS} 5\right)$ and $3^{\prime} \beta$-globin gene region $\left(3^{\prime} \mathrm{HS} 1\right)$, and the thin arrow $5^{\prime}$ to the $\beta$-globin gene is a gene-specific HS. The curved black arrow represents the postulated LCR-mediated activation of the $\beta$-globin gene. (B) Inactivation of the $\beta$-globin gene by homologous integration of the Friend LTR/hygro ${ }^{R}$ gene into the LCR (HR-MEL). Straight solid arrows represent DNase I HS detected in our HR, including a new site in the Friend virus LTR. The stippled arrows represent loss of DNase I HS in LCR 5'HSI and $5^{\prime} \beta$ promoter regions. The LCR effect on $\beta$-globin gene activation in N-MEL (curved stippled arrow and open rectangle) is now replaced by an LCR-mediated, inducible activation of the Friend LTR/hygro ${ }^{R}$ gene (curved solid arrow). 
equally well at all developmental stages when linked to the LCR. In transgenic constructs containing linked $\gamma$ and $\beta$-globin genes, the level of stage-specific expression of each gene has been shown to be affected by the positions of these genes relative to the LCR (Blom van Assendelft et al. 1978; Behringer et al. 1990; Enver et al. 1990; Lindenbaum and Grosveld 1990; Hanscombe et al. 1991). In combination, these results suggest that the outcome of competition between genes for activation by the LCR is determined both by stage-specific elements immediately flanking the genes, as proposed by Choi and Engel (1988), and by their relative distances from the LCR, with the more proximal gene having an advantage (Hanscombe et al. 1991). In this view, the stage-specific and autonomous turning off of the $\epsilon$ - and $\gamma$-globin genes would be the rate-limiting steps in the subsequent LCRdependent transcriptional activation of the $\beta$-globin gene during development. Thus, promoter competition for LCR elements appears to be the principal mechanism for $\beta$-globin gene switching in humans and chickens, as proposed originally by Choi and Engel (1988). In this context, it is not surprising that a competition between the Friend enhancer/promoter hygro ${ }^{\mathrm{R}}$ cassette and the $\beta$-globin gene may also occur, given the preferential activity of the Friend LTR in erythroid cells /Cowie and Myers 1988) and its proximity to the LCR. In essence, the inactivation of the $\beta$-globin gene in our homologous recombinants may be through a mechanism similar to that operating in development, when the active $\epsilon$-globin gene out-competes the $\beta$-globin gene for the effects of the LCR.

Others have reported the insertion of positive selectable marker genes into the human $\beta$-globin locus in MEL/human hybrids by HR. In one case /Smithies et al. 1985), two transcription units, an SV40 enhancer/promoter-driven neomycin resistance $\left(\right.$ neo $\left.^{\mathrm{R}}\right)$ gene and an additional truncated $\beta$-globin gene, were inserted at a site $2.3 \mathrm{~kb}$ upstream from the cap site of the human $\beta$-globin gene. Expression of the endogenous $\beta$-globin gene was reduced, and the neo ${ }^{\mathrm{R}}$ gene displayed inducible expression (Nandi et al. 1988). The observed decrease in $\beta$-globin expression in this recombinant is somewhat difficult to interpret, given the introduction of two additional genes into this locus. However, in the second case (Sheseley et al. 1991), insertion of a single polyoma enhancer/tk promoter-driven ${ }^{2} o^{\mathrm{R}}$ gene $\sim 600 \mathrm{bp}$ upstream of the $\beta$-globin gene cap site did not significantly affect expression of the downstream $\beta$-globin gene. Although this result and our results seem contradictory, they can be reconciled by considering the model described above, in which competition between genes for the LCR is influenced by their relative distances from the LCR and/or the differential affinity of stage-specific elements for the LCR. In this context the proximity of the Friend virus promoter/enhancer to the LCR in our targeted clones could result in its successful competition over the distantly located $\beta$-globin gene promoter for LCR-conferred inducible expression. In contrast, given the similar locations of the neo ${ }^{\mathrm{R}}$ and $\beta$-globin genes $\sim 50 \mathrm{~kb}$ downstream from the LCR, less effective competition for the LCR would occur. Sequences within the Friend virus enhancer/promoter may also be stronger competitors for the LCR than the sequences within the polyoma cassette in the MEL cell background.

It is also possible that the insertion of the hygro ${ }^{\mathrm{R}}$ gene between 5'HS1 and 5'HS2 may disrupt critical spacing requirements for LCR activity, including the formation of $5^{\prime} \mathrm{HS1}$. We believe, however, that several observations make this a less likely explanation for the inactivation of the downstream $\beta$-globin gene than the promoter/enhancer competition model. Stable transfection assays in erythroid cells in which the $\beta$-globin gene is linked to fragments of the LCR have revealed that in combination with other HS sequences, $5^{\prime} \mathrm{HSl}$ can augment globin gene expression by a maximum of only twofold /Collis et al. 1990). Moreover, in contrast to $5^{\prime} \mathrm{HS} 2,5^{\prime} \mathrm{HS} 3$, or 5'HS4, sequences within 5'HS1 do not confer elevated globin gene expression autonomously. Furthermore, the retention of sequences comprising $5^{\prime} \mathrm{HSl}$ is not sufficient to form an active $\beta$-globin chromatin domain or activate $\beta$-globin gene expression in the Hispanic $(\gamma \delta \beta)^{0}$ thalassemia, a de novo $35-\mathrm{kb}$ deletion that removes all LCR elements $5^{\prime}$ of $5^{\prime} \mathrm{HS} 1$ (Driscoll et al. 1989; Forrester et al. 1990). It has also been reported that $\beta$-globin gene expression is not altered by a naturally occurring $3.03-\mathrm{kb}$ deletion upstream of the $\epsilon$-globin gene, including sequences comprising 5'HS1 (Kulozik et al. 1991). In addition, the hygro ${ }^{\mathrm{R}}$ genes introduced into the LCR in our homologous recombinants demonstrate inducible expression, in the absence of $5^{\prime} \mathrm{HSl}$. Thus, $5^{\prime} \mathrm{HS} 1$ is neither necessary nor sufficient for the erythroid specific expression of genes under LCR control.

Regardless of the mechanism of $\beta$-globin inactivation in our targeted recombinants, our results emphasize the need to remove the positive selectable marker gene following HR, if a positive selection HR strategy is to be useful in the analysis of regulatory regions. Recently, several in/out strategies to delete sequences inserted by HR have been described (Reid et al. 1990; Dale and Ow 1991; Hasty et al. 1991; O'Gorman et al. 1991; Valancius and Smithies 1991). We are currently investigating the feasibility of these methods for use in the functional analysis of the human $\beta$-globin LCR by HR.

\section{Materials and methods}

\section{Targeting construct preparation}

The targeting construct (p5' $\epsilon$ Hygrotk) is an 18-kb pUC19-based plasmid that contains a 9-kb 5' $\epsilon$ EcoRI-BamHI DNA fragment, with the hygro ${ }^{\mathrm{R}}$ gene (1.5-kb SacI-BglII fragment; Santerre et al. $1984)$ inserted at a unique $\mathrm{HpaI}$ site and the HSV tk gene $(2.5-\mathrm{kb}$ BgIII-BamHI fragment of pHSV 106; McKnight and Gavis 1980) inserted at the terminal BamHI site (see Fig. 1). Both genes are driven by a $0.5-\mathrm{kb}$ KpnI-Pst fragment that contains the Friend virus LTR enhancer/promoter sequences (Clark et al. 1985) to allow high-level constitutive expression in the hybrid erythroleukemia cells. The hygro ${ }^{\mathrm{R}}$ gene contains a tandem duplicated 0.85-kb BglII-BamHI fragment with the SV40 poly(A) addition signal sequence and small $t$ antigen intronic splicing sequence. 


\section{Cell culture}

The parent cells for homologous recombination (N-MEL-129 ${ }^{\circ}$, which contain a copy of normal human chromosome 11 , are one of the MEL/human hybrid cell lines described previously (N. MEL; Forrester et al. 1990). Cells were maintained in nonselective Dulbecco's modified Eagle medium (DMEM) with 10\% ( $\mathrm{vol} / \mathrm{vol}$ ) heat-inactivated bovine calf serum and periodically enriched for the presence of human chromosome 11 by panning with a monoclonal antibody as described (Yagi et al. 1987; Forrester et al. 1990).

For electroporation, $1 \times 10^{7}$ cells were resuspended in $0.6 \mathrm{ml}$ of DMEM without serum, and $5 \mu \mathrm{g}$ of FspI-linearized targeting vector was added. After incubation at room temperature for 10-15 min, electroporation was performed at $350 \mu \mathrm{F}$ capacitance and $250 \mathrm{~V}$ by use of a BTX device. After 10-15 min at room temperature, cells were diluted into warm growth medium and plated in either $150-\mathrm{mm}$ petri dishes or 48-well plates. Hygromycin B $(0.6-0.8 \mathrm{mg} / \mathrm{ml}$; Calbiochem) was added the next day for 2 weeks, and gancyclovir $(10 \mu \mathrm{m}$; Syntex $)$ was then added for an additional week. After both positive and negative selections, drug-resistant cells were maintained in $0.5 \mathrm{mg} / \mathrm{ml}$ of hygromycin B-containing media. Several sib selections were performed in microtiter plates to isolate pure populations of recombinant cells.

Induction of erythroid differentiation of cells was performed by the addition of $5 \mathrm{mM} \mathrm{HMBA}$ (Sigma) to the culture medium for 3 days. 5-Azacytidine (Sigma) treatment was accomplished by addition to a final concentration of $3 \mu \mathrm{M}$ to the culture medium for $20 \mathrm{hr}$, and surviving cells were allowed to recover by cultivation in normal medium for 1 week.

\section{$P C R$}

PCR reactions were performed using standard conditions in a total reaction volume of $50 \mu \mathrm{l}$. Other ingredients such as glycerol $(10 \%)$ or tetramethylammonium chloride (TMAC, $50 \mu \mathrm{M})$ were added to PCR reactions when crude cell lysates were used. Thirty-five cycles were performed with denaturation for $1 \mathrm{~min}$ at $92^{\circ} \mathrm{C}$, annealing for $30 \mathrm{sec}$ at $63^{\circ} \mathrm{C}$, and extension for $2.5 \mathrm{~min}$ at $72^{\circ} \mathrm{C}$. A portion of each sample $(15 \mu \mathrm{l})$ was analyzed by electrophoresis in $1 \%$ agarose gels. Putative homologous recombinants were identified by the PCR product size of ethidium bromide-stained bands in the gel or after Southern blotting and probing with a random-primed $5^{\prime} \epsilon 1.0-\mathrm{kb} H$ paI-EcoRI fragment. Primer sequences are as follows: PCR 1 (vector, $3^{\prime}$ homology region), 5'-CAG GGT GAA AGG GTA TCG CTA C-3'; PCR 99 (genomic, 5' junction), 5'-GCA CTC CAG CCT CCA GAG CG$3^{\prime}$; PCR H1 (vector, hygro ${ }^{\mathrm{R}}$ gene), 5'-ATC TCA TTG CCC CCG GAC GA-3'; PCR 8 (vector, 5' homology region), 5'-CCC ATC AAA TTC CCT GAC CG-3'.

\section{Chromatin structure and genomic Southern blotting}

Isolation of nuclei, DNase I digestions, purification and restriction enzyme digestion of genomic DNA, and Southern blotting were as described (Forrester et al. 1990). Probes for hybridization were labeled by the nick translation or random priming methods. The junction probe $10.3-\mathrm{kb}$ EcoRI-EcoRV probe used in Fig. 3) was made by a PCR-based primer extension method (Bednarczuk et al. 1991).

\section{RNase protection analysis}

Total cellular RNA from cultured and HMBA-induced cells was prepared by the RNAzol-based quick method (Kim et al. 1990) as recommended by the manufacturer (Cinna/Biotecx), and the purified RNA was resuspended in water according to the total cell number per volume (RNA from $1 \times 10^{7}$ cells $/ 50 \mu$ l of water).

RNase protection assays were performed as originally described (Zinn et al. 1983; Kim et al. 1990). Antisense probe RNAs were prepared in vitro with SP6, T7, or T3 RNA polymerase (Promega) using standard methods (Zinn et al. 1983; Melton et al. 1984; Kim et al. 1990). As controls, mouse $\alpha$ and/or $\beta$-globin gene probes were also included in the reaction containing $1 \mu \mathrm{l}$ of purified cellular RNA. The antisense RNA probes are as follows: human $\beta$-globin, $\mathrm{pSP} 64 \mathrm{~h} \beta^{351}$ as described in Charnay et al. (1984); hygro ${ }^{\mathrm{R}}$, pVZhygro ${ }^{\mathrm{R}}$ containing a $295-\mathrm{bp}$ HindIII-EcoRI fragment of the hygro ${ }^{\mathrm{R}}$ gene; mouse $\alpha$-globin, pSP64m $\alpha$ containing a BamHI-PstI fragment of the mouse genomic $\alpha$-globin gene; mouse $\beta$-globin, pGEMm $\beta$ containing a 0.8 -kb HindIII-BamHI fragment of the genomic mouse $\beta$-globin gene (two protected bands corresponding to exon 1 and exon 2 ).

\section{Acknowledgments}

We thank our colleagues at the Hutchinson Center for encouragement and helpful discussions. We also thank Thalia Papayannopoulou for panning hybrid cells and Rick Myers and Frank Grosveld for plasmids. The technical assistance of Agnes Telling is gratefully acknowledged. This work was supported by U.S. Public Health Service grant DK-31232 to M.G., a grant from the James McDonnell Foundation to E.E., and a Cooley's Anemia Foundation award to C.K.

The publication costs of this article were defrayed in part by payment of page charges. This article must therefore be hereby marked "advertisement" in accordance with 18 USC section 1734 solely to indicate this fact.

\section{References}

Antequera, F., J. Boyes, and A. Bird. 1990. High levels of de novo methylation and altered chromatin structure at $\mathrm{CpG}$ islands in cell lines. Cell 62: 503-514.

Bednarczuk, T.A., R.C. Wiggins, and G.W. Konat. 1991. Generation of high efficiency, single stranded DNA hybridization probes by PCR. BioTechniques 10: 478 .

Behringer, R.R., T.M. Ryan, R.D. Palmiter, R.L. Brinster, and T.M. Townes. 1990. Human $\gamma$ - to $\beta$-globin gene switching in transgenic mice. Genes \& Dev. 4: 380-389.

Blom van Assendelft, G., O. Hanscombe, F. Grosveld, and D.R. Greaves. 1989. The $\beta$-globin dominant control region activated homologous and heterologous promoters in a tissuespecific manner. Cell 56: 969-977.

Cao, S.X., P.D. Gutman, H.P.G. Dave, and A.N. Schechter. 1989. Identification of a transcriptional silencer in the $5^{\prime}$ flanking region of the human $\epsilon$-globin gene. Proc. Natl. Acad. Sci. 86: 5306-5309.

Capecchi, M. 1989. Altering the genome by homologous recombination. Science 244:1288-1292.

Charnay, P., R. Treisman, P. Mellon, M. Chao, R. Axel, and T. Maniatis. 1984. Differences in human $\alpha$ - and $\beta$-globin gene expression in mouse erythroleukemia cells: The role of intragenic sequences. Cell 38: 251-263.

Choi, O.R. and J.D. Engel. 1988. Developmental regulation of $\beta$-globin gene switching. Cell 55: 17-26.

Clark, S.P., R. Kaufold, A. Chan, and T.W. Mak. 1985. Comparison of the transcriptional properties of the Friend and Moloney retrovirus long terminal repeats: Importance of tandem duplications and of the core enhancer sequence. Virology 
144: $481-494$

Collis, P., M. Antoniou, and F. Grosveld. 1990. Determination of the minimal requirements within the human $\beta$-globin gene and the dominant control region for high level expression. EMBO I. 9: 233-240.

Compere, S.J. and R.D. Palmiter. 1981. DNA methylation controls the inducibility of the mouse methallothionein-1 gene in lymphoid cells. Cell 25: 233-240.

Cowie, A. and R.M. Myers. 1988. DNA sequences involved in transcriptional regulation of the mouse $\beta$-globin promoter in murine erythroleukemia cells. Mol. Cell. Biol. 8: 31223128.

Curtin, P., M. Pirastu, Y.W. Kan, J.A. Gobert-Jones, A.D. Stephenes, and H. Lehman. 1985. A distinct deletion affects $\beta$-globin gene function in an atypical $\gamma \delta \beta$-thalassemia. $/$. Clin. Invest. 76:1554-1558.

Curtin, P., D. Liu, W. Liu, J.C. Chang, and Y.W. Kan. 1989. Human $\beta$-globin gene expression in transgenic mice is enhanced by a distant DNase I hypersensitive site. Proc. Natl. Acad. Sci, 86: 7082-7086.

Dale, E.C. and D.W. Ow, 1991. Gene transfer with subsequent removal of the selection gene from the host genome. Proc. Natl. Acad. Sci. 88: 10558-10562.

Dillon, N. and F. Grosveld. 1991. Human $\gamma$-globin genes silenced independently of other genes in the $\beta$-globin locus. Nature 350: 252-254.

Driscoll, M.C., C.S. Dobkin, and B.P. Alter. 1989. $\gamma \delta \beta^{0}$ thalassemia due to a de novo mutation deleting the $5^{\prime} \beta$-globin locus activating region hypersensitive sites. Proc. Natl. Acad. Sci. 86: 7470-7474.

Enver, T., N. Raich, A.J. Ebens, T. Papayannopoulou, and G. Stamatoyannopoulos. 1990. Developmental regulation of human fetal-to-adult globin gene switching in transgenic mice. Nature 344: 309-313.

Epner, E., W.C. Forrester, and M. Groudine. 1988. Asynchronous DNA replication within the human $\beta$-globin gene locus. Proc. Natl. Acad. Sci. 85: 8081-8085.

Epner, E., W.C. Forrester, C. Kim, A. Telling, T. Enver, M. Brice, T. Papayannopoulou, and M. Groudine. 1991. Chromatin structure and DNA replication patterns in normal and mutant $\beta$-globin gene loci. In The regulation of hemoglobin switching (ed. G. Stamatoyannopoulos and A.W. Nienhuis) pp. 153-177, The Johns Hopkins University Press, Baltimore/London.

Evans, T., G. Felsenfeld, and M. Reitman. 1990. Control of globin gene transcription. Annu. Rev. Cell Biol. 6: 95-124.

Forrester, W.C., E. Epner, M.C. Driscoll, T. Enver, M. Brice, T. Papayannopoulou, and M. Groudine. 1990. A deletion of the human $\beta$-globin locus activation region causes a major alteration in chromatin structure and replication across the entire $\beta$-globin locus. Genes \& Dev. 4: 1637-1649.

Forrester, W.C., C. Thompson, J.T. Elder, and M. Groudine. 1986. A developmentally stable chromatin structure in the human $\beta$-globin gene cluster. Proc. Natl. Acad. Sci. 83: $1359-1363$.

Forrester, W.C., S. Takegawa, T. Papayannopoulou, and M. Groudine. 1987. Evidence for a locus activation region: The formation of developmentally stable hypersensitive sites in globin-expressing hybrids. Nucleic Acids Res. 15: 1015910177.

Forrester, W.C., U. Novak, R. Gelinas, and M. Groudine. 1989. Molecular analysis of the human $\beta$-globin locus activation region. Proc. Natl. Acad. Sci. 86: 5439-5443.

Grosveld, F., G. Blom van Assendelft, D.R. Greaves, and G. Kollias. 1987. Position independent, high level expression of the human $\beta$-globin gene in transgenic mice. Cell 51: 975-
985.

Groudine, M., R. Eisenman, and H. Weintraub. 1981. Chromatin structure of endogenous retroviral genes and activation by an inhibitor of DNA methylation. Nature 292: 311-317.

Groudine, M., T. Kohwi-Shigematsu, R. Gelinas, G. Stamatoyannopoulos, and T. Papayannopoulou. 1983. Human fetal to adult hemoglobin switching: Changes in chromatin structure of the $\beta$-globin gene locus. Proc. Natl. Acad. Sci. 80: $7551-7555$.

Hanscombe, O., D. Whyatt, P. Fraser, N. Yannoutsos, D. Greaves, N. Dillon, and F. Grosveld. 1991. Importance of globin gene order for correct developmental expression. Genes \& Dev. 5: 1387-1394.

Hasty, P., R. Ramirez-Solis, R. Krumlauf, and A. Bradley. 1991. Introduction of a subtle mutation into the Hox-2.6 locus in embryonic stem cells. Nature 350: 243-246.

Higgs, D.R., W.G. Wood, A.P. Jarman, J. Sharpe, J. Lida, I.M Pretorius, and $\mathrm{H}$. Ayyub. 1990. A major positive regulatory region located far upstream of the human $\alpha$-globin locus. Genes \& Dev. 4: 1588-1601.

Jones, P.A., S.M. Taylor, T. Mohandas, and L.J. Shapiro. 1982. Cell-cycle specific reactivation of an inactive X-chromosome locus by 5-azadeoxycytidine. Proc. Natl. Acad. Sci. 79: $1215-1219$

Kim, H.S. and O. Smithies. 1988. Recombinant fragment assay for gene targeting based on the polymerase chain reaction. Nucleic Acids Res. 18: 8887-8903.

Kim, C.G., S.L. Swendeman, K.M. Barnhart, and M. Sheffery. 1990. Promoter elements and erythroid cell nuclear factors that regulate $\alpha$-globin gene transcription in vitro. Mol. Cell. Biol. 10: 5958-5966.

Kulozik, A.E., S. Bail, A. Bellan-Koch, C.R. Bartrann, E. Kohne, and E. Kleihauer. 1991. The proximal element of the $\beta$-globin locus control region is not functionally required in vivo. J. Clin. Invest. 87: 2142-2146.

Ley, T.J., J. De Simone, N.P. Anagnon, G.H. Keller, R.K. Humphries, P.H. Turner, N.S. Young, P. Heller, and A.W. Nienhuis. 1982. 5-Azacytidine selectively increases $\gamma$-globin synthesis in patient with $\beta^{+}$thalassemia. N. Engl. I. Med. 307: 1469-1475.

Li, Q., B. Zhou, P. Powers, T. Enver, and G. Stamatoyannopoulos. 1990. $\beta$-Globin locus activation regions: Conservation of organization, structure, and function. Proc. Natl. Acad. Sci. 87: 8207-8211.

Lindenbaum, M. and F. Grosveld. 1990. An in vitro globin gene switching model based on differentiated embryonic stem cells. Genes \& Dev. 4: 2075-2085.

Mansour, S.L., K.R. Thomas, and M. Capecchi. 1988. Disruption of the proto-oncogene int- 2 in mouse embryo-derived stem cells: A general strategy for targeting mutations to nonselectable genes. Nature 336: 348-352.

McKnight, S.L. and E.R. Gavis. 1980. Expression of the herpes thymidine kinase gene in Xenopus laevis oocytes: An assay for the study of deletion mutants constructed in vitro. $\mathrm{Nu}$ cleic Acids Res. 8: 5931-5948.

Melton, D.A., P.A. Krieg, M.R. Rebagliati, T. Maniatis, K. Zinn, and M.R. Green. 1984. Efficient in vitro synthesis of biologically active RNA and RNA hybridization probes from plasmids containing a bacteriophage SP6 promoter. Nucleic Acids Res. 12: 7035-7056.

Moon, A.M. and T.J. Ley. 1990. Conservation of the primary structure, organization, and function of the human and mouse $\beta$-globin locus activating regions. Proc. Natl. Acad. Sci. 87: 7693-7697.

- 1991. Functional properties of the $\beta$-globin locus control region in K562 erythroleukemia cells. Blood 77: 2272-2284. 
Nandi, A.K., R.S. Roginski, R.G. Gregg, and O. Smithies. 1988. Regulated expression of genes inserted at the human chromosomal $\beta$-globin locus by homologous recombination. Proc. Natl. Acad. Sci. 85: 3845-3849.

O'Gorman, S., D.T. Fox, and G.M. Wahl. 1991. Recombinasemediated gene activation and site-specific integration in mammalian cells. Science 251: 1351-1355.

Orkin, S.H. 1990. Globin gene regulation and switching: Circa 1990. Cell 63: 665-672.

Raich, N., T. Enver, B. Nakamoto, B. Josephson, T. Papayannopoulou, and G. Stamatoyannopoulos. 1990. Autonomous developmental control of human embryonic globin switching in transgenic mice. Science 250: 1147-1149.

Reid, L.H., R.G. Gregs, O. Smithies, and B.H. Kohler. 1990. Regulatory elements in the introns of the HPRT gene are necessary for its expression in mouse embryonic stem cells. Proc. Natl. Acad. Sci. 87: 4299-4303.

Reitman, M., E. Lee, H. Westphal, and G. Felsenfeld. 1990. Siteindependent expression of the chicken $\beta^{\mathrm{A}}$-globin gene in transgenic mice. Nature 348: 750-752.

Ryan, T.M., R.R. Behringer, N.C. Martin, T.M. Townes, R.D. Palmiter, and R.L. Brinster. 1989. A single erythroid-specific DNase I super-hypersensitive site activates high levels of human $\beta$-globin gene expression in transgenic mice. Genes \& Dev. 3: 314-323.

Santerre, R.F., N.E. Allen, J.N. Hobbs Jr., R.N. Rao, and R.J. Schmidt. 1984. Expression of prokaryotic genes for hygromycin B and G418 resistance as dominant-selection markers in mouse L cells. Gene 30: 147-156.

Shesely, E.G., H.S. Kim, W.R. Shehee, T. Papayannopoulou, O. Smithies, and B.W. Popovich. 1991. Correction of a human $\beta^{\text {s }}$-globin gene by gene targeting. Proc. Natl. Acad. Sci. 88: 4294-4298.

Smithies, O., R.G. Gregg, S.S. Boggs, M.A. Koralewski, and R.S. Kucherlapati. 1985. Insertion of DNA sequences into the human chromosomal $\beta$-globin locus by homologous recombination. Nature 317: 230-234.

Stamatoyannopoulos, G. 1991. Human hemoglobin switching. Science 252: 383.

Talbot, D., P. Collis, M. Antoniou, M. Vidal, F. Grosveld, and D.R. Greaves. 1989. A dominant control region from the human $\beta$-globin locus conferring integration-independent gene expression. Nature 338: 352-355.

Townes, T.M. and R.R. Behringer. 1990. Human globin locus activation region (LAR): Role in temporal control. Trends Genet. 6: 219-223.

Tuan, D., W. Solomon, Q. Li, and I.M. London. 1985. The " $\beta$ like globin" gene domain in human erythroid cells. Proc. Natl. Acad. Sci. 82: 6384-6388.

Tuan, D.Y., W.B. Solomon, I.M. London, and D.P. Lee. 1989. An erythroid-specific, developmental-stage independent enhancer far upstream of the human " $\beta$-like globin" genes. Proc. Natl. Acad. Sci. 86: 2554-2558.

Valancius, V. and O. Smithies. 1991. Testing an "In-Out" targeting procedure for making subtle genomic modifications in mouse embryonic stem cells. Mol. Cell. Biol. 11: 14021408.

Van der Ploeg, L.H.T., A. Konings, M. Oorst, D. Roos, L. Bernini, and R.A. Flavell. 1986. $\gamma$ - $\beta$-thalassemia studies showing that deletion of the $\gamma$ - and $\delta$-genes influences $\beta$-globin gene expression in man. Nature 283: 637-642.

Yagi, M., G. Stamatoyannopoulos, and T. Papayannopoulou. 1987. Monoclonal antibody 53.6 recognizes a novel proliferation-associated antigen encoded on human chromosome 11. I. Immunol. 136: 2208-2212.

Zinn, K., D. DiMaio, and T. Maniatis. 1983. Identification of two distinct regulatory regions adjacent to the human $\beta$-interferon gene. Cell 34: 865-879. 


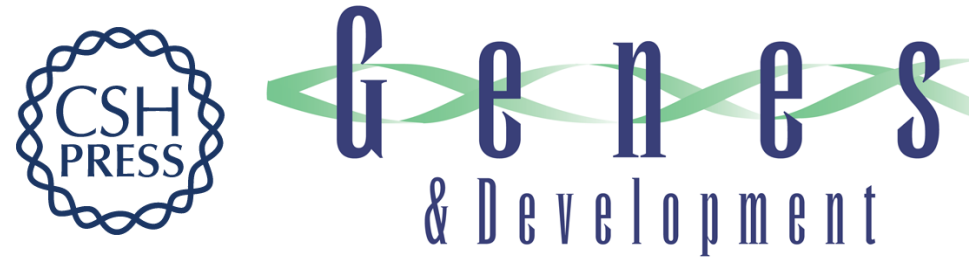

\section{Inactivation of the human beta-globin gene by targeted insertion into the beta-globin locus control region.}

C G Kim, E M Epner, W C Forrester, et al.

Genes Dev. 1992, 6:

Access the most recent version at doi:10.1101/gad.6.6.928

References This article cites 61 articles, 30 of which can be accessed free at:

http://genesdev.cshlp.org/content/6/6/928.full.html\#ref-list-1

License

Email Alerting Receive free email alerts when new articles cite this article - sign up in the box at the top Service right corner of the article or click here.

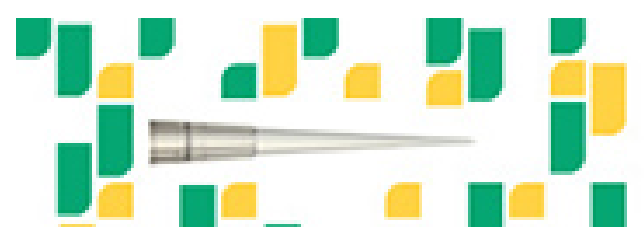

Focused on your science.

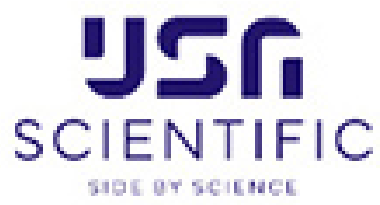

Copyright (c) Cold Spring Harbor Laboratory Press 